\title{
Polyethylene with Reverse Co-monomer Incorporation: From an Industrial Serendipitous Discovery to Fundamental Understanding
}

\author{
Dimitrije Cicmil, Jurjen Meeuwissen, Aurélien Vantomme, Jian Wang, Ilse K. van Ravenhorst, \\ Hendrik E. van der Bij, Ara Muñoz-Murillo, and Bert M. Weckhuysen*
}

\begin{abstract}
A triethylaluminium(TEAl)-modified Phillips ethylene polymerisation $\mathrm{Cr} / \mathrm{Ti} / \mathrm{SiO} \mathrm{O}_{2}$ catalyst has been developed with two distinct active regions positioned respectively in the inner core and outer shell of the catalyst particle. DRIFTS, EPR, UV-Vis-NIR DRS, STXM, SEM-EDX and GPC-IR studies revealed that the catalyst produces simultaneously two different polymers, i.e., low molecular weight linear-chain polyethylene in the Ti-abundant catalyst particle shell and high molecular weight short-chain branched polyethylene in the Tiscarce catalyst particle core. Co-monomers for the short-chain branched polymer were generated in situ within the TEAlimpregnated confined space of the Ti-scarce catalyst particle core in close proximity to the active sites that produced the high molecular weight polymer. These results demonstrate that the catalyst particle architecture directly affects polymer composition, offering the perspective of making high-performance polyethylene from a single reactor system using this modified Phillips catalyst.
\end{abstract}

Several years ago at an industrial ethylene polymerisation plant, the in situ generation of co-monomer on a $\mathrm{Cr}$ polymerization line using the well-known $\mathrm{Cr} / \mathrm{Ti} / \mathrm{SiO}_{2}$ Phillips-type catalyst was reported. ${ }^{[1-8]}$ Hence, the co-feeding of 1-hexene was significantly reduced in order to keep a polymer with similar content of co-monomer. The interesting finding was that 1-hexene was the major component, while butene and other oligomers were present in lower concentration. Moreover, the properties of the polyethylene produced were not

[*] D. Cicmil, I. K. van Ravenhorst, Dr. H. E. van der Bij,

Dr. A. Muñoz-Murillo, Prof. Dr. B. M. Weckhuysen

Inorganic Chemistry and Catalysis

Debye Institute for Nanomaterials Science, Utrecht University

Universiteitsweg 99, 3584 CG Utrecht (The Netherlands)

E-mail:b.m.weckhuysen@uu.nl

Dr. J. Meeuwissen, Dr. A. Vantomme

Refining \& Chemicals, Total Research and Technology Feluy

Zone Industrielle C, 7181 Seneffe (Belgium)

Dr. J. Wang

Soft X-ray Spectromicroscopy, Canadian Light Source Inc.

44 Innovation Boulevard, SK S7N 2V3 Saskatoon (Canada)

(1) Supporting information for this article (including details on the catalyst materials, their preparation and related catalyst and polymer characterisation) is available on the WWW under http://dx.doi.org/ 10.1002/anie.201506718.

(C) 2015 The Authors. Published by Wiley-VCH Verlag GmbH \& Co. $\mathrm{KGaA}$. This is an open access article under the terms of the Creative Commons Attribution Non-Commercial License, which permits use, distribution and reproduction in any medium, provided the original work is properly cited and is not used for commercial purposes. affected despite the presence of butene. On the contrary, the polymer made even exhibited some improvements. The hypothetical explanation for in situ co-monomer generation was a contamination of the recycling feeds by triethylaluminium (TEAl), as there were several lines with a common recycling section. One of the polymerisation lines was running a Ziegler-Natta catalyst with TEAl as co-catalyst, ${ }^{[9,10]}$ while the other polymerisation lines ran with a $\mathrm{Cr} / \mathrm{Ti} / \mathrm{SiO}_{2}$ Phillipstype catalyst without any co-catalyst.

Preliminary tests at both pilot and bench scales confirmed the in situ generation of co-monomer with a $\mathrm{Cr} / \mathrm{Ti} / \mathrm{SiO}_{2}$ catalyst and TEAl. The observed phenomena could be confirmed, as illustrated in Figure 1, by performing slurryphase ethylene polymerisation experiments in a 4 litre-sized semi-batch reactor. The polymerisation conditions were chosen to target the same molecular weight distribution and co-monomer content in the polymer (Table S1 and S2 in the Supporting Information). Hence, 1-hexene was added in one experiment during the polymerisation when the Phillips $\mathrm{Cr} /$ $\mathrm{Ti} / \mathrm{SiO}_{2}$ catalyst under investigation was tested without TEAl, as no co-monomer was in situ generated in that particular case. In the second experiment, in situ oligomerisation was induced by modification of the catalyst with TEAl. GPC-IR analysis of the polymers produced clearly shows that less comonomer was incorporated in the short polyethylene chains than in the long chains when it is generated in situ. Consequently, this so-called reverse co-monomer incorporation is

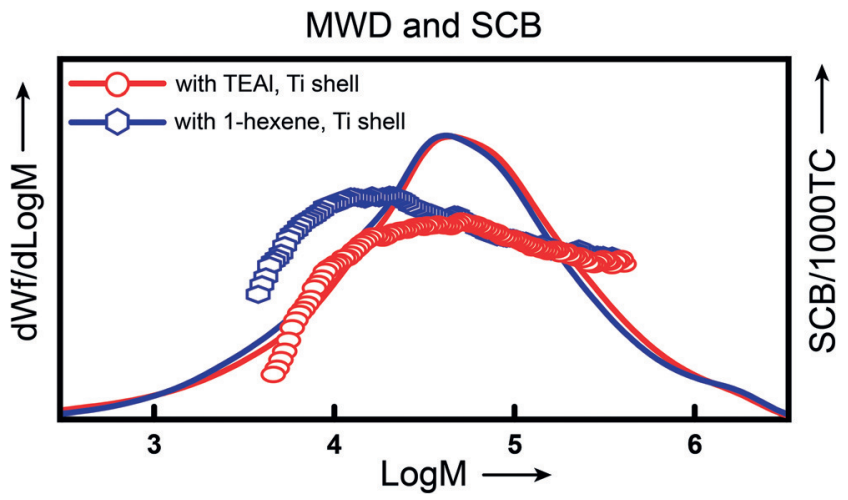

Figure 1. Molecular weight distribution (MWD) and short chain branching distribution (SCBD) of the polyethylene produced with the developed Phillips $\mathrm{Cr} / \mathrm{Ti} / \mathrm{SiO}_{2}$ catalyst in a 4 litre-sized semi-batch reactor, with and without externally added 1-hexene co-monomer. Reverse incorporation of co-monomer into longer polyethylene chains is boosted when co-monomer is in situ generated, while the overall amount of incorporated olefins was kept similar as confirmed by ${ }^{13} \mathrm{C}$ NMR analysis. 
enhanced when the co-monomer is generated in situ in the presence of TEAl. ${ }^{[11]}$ This result came as a positive surprise as more co-monomer incorporated in the high molecular weight fraction of the polymer leads to better mechanical properties. $^{[12]}$ Thus the fundamental question was: what are the underlying principles for the production of this polymer using a TEAl-modified $\mathrm{Cr} / \mathrm{Ti} / \mathrm{SiO}_{2}$ catalyst ?

Ti has been used in the polymer industry since several decades to lower the molecular weight (MW) and broaden the molecular weight distribution (MWD) of the polymer. ${ }^{[13-18]}$ However, Deslauriers and McDaniel revealed that the addition of $\mathrm{Ti}$ to the $\mathrm{SiO}_{2}$ support also leads to an improved distribution of co-monomer in the polymer because the $\mathrm{Cr} / \mathrm{Ti} /$ $\mathrm{SiO}_{2}$ sites give low molecular weight polymer and have low co-monomer reactivity. ${ }^{[19]}$

Here, we present a new type of Phillips $\mathrm{Cr} / \mathrm{Ti} / \mathrm{SiO}_{2}$ catalyst, which was prepared from a commercially available $\mathrm{Cr} / \mathrm{SiO}_{2}$ pre-catalyst by selective surface titanation on the catalyst particle's outer shell and subsequent activation, according to the procedure described in Debras et al. ${ }^{[18]}$ By pre-contacting the catalyst with $\mathrm{TEAl}$, in situ ethylene oligomerisation sites could be generated. ${ }^{[1]}$ Further details on catalyst synthesis can be found in the Supporting Information. Typically, an olefinic co-monomer (i.e., 1hexene) is added externally to the reaction mixture and has to diffuse through the growing polymer and catalyst material to arrive at the catalytic sites. We envisioned that it would be advantageous if the co-monomer was generated on the TEAlmodified active sites within the Ti-scarce catalyst particle close to the active sites that make a high molecular weight polymer. Therefore, in situ produced olefins (e.g., 1-hexene) would be incorporated into longer polyethylene chains. We show for the first time that we can relate these macroscale polymer properties to nanoscale chemical imaging of (earlystage polymerisation) $\mathrm{Cr} / \mathrm{Ti} / \mathrm{SiO}_{2}$ catalyst particles by making use of scanning transmission X-ray microscopy (STXM) ${ }^{[20-22]}$ as an alternative approach to the research of Barzan et al., who studied hydrosilane compounds as co-catalyst. ${ }^{[23]}$

In a first series of experiments, the catalyst and its polymerisation behaviour were studied using in situ diffuse reflectance infrared Fourier transform (DRIFT) spectroscopy. The obtained DRIFT spectra measured as a function of time-on-stream for the $\mathrm{Cr} / \mathrm{Ti} / \mathrm{SiO}_{2}$ catalyst under study are shown in Figure $2 \mathrm{a}$. The initial spectrum corresponds with a highly dehydroxylated catalyst as testified by the sharp silanol and titanol stretching bands located at $3747 \mathrm{~cm}^{-1}$ and $3722 \mathrm{~cm}^{-1}$, respectively. During the first $5 \mathrm{~min}$, the injection of the TEAl co-catalyst in heptane, for a $\mathrm{Al}: \mathrm{Cr}$ molar ratio of 2 , can be noted by the increase of the methyl and methylene stretching bands of these compounds in the $2800-3000 \mathrm{~cm}^{-1}$ $\mathrm{CH}$ stretching region. ${ }^{[24-28]}$ It must be noted that the addition of TEAl did not lead to a significant decrease of the silanol and titanol groups, suggesting that the added TEAl was also consumed for the reduction of $\mathrm{Cr}^{6+}$ to $\mathrm{Cr}^{2+}, \mathrm{Cr}^{3+}$ and $\mathrm{Cr}^{5+}$ species, ${ }^{[29-38]}$ for the transformation of a portion of the polymerisation into the oligomerisation active sites as well as for the scavenging of poisons. ${ }^{[1]}$ Flushing of heptane revealed complex vibrational features of TEAl in the $\mathrm{CH}$ stretching region, suggesting alkylation of some of the $\mathrm{Cr}$ sites. UV-Vis-NIR DRS measurements (Figure $2 \mathrm{~d}$ ) of the catalyst at this point show that TEAl is inducing a small decrease in the intensity of mono- and polychromate $\mathrm{O} \rightarrow \mathrm{Cr}^{6+}$ CT bands at 36000,28000 and $21500 \mathrm{~cm}^{-1}$, accompanied by the appearance of the $\mathrm{d}-\mathrm{d}$ bands at 16000 and $10000 \mathrm{~cm}^{-1}$ due to the ${ }^{4} \mathrm{~A}_{2 \mathrm{~g}} \rightarrow{ }^{4} \mathrm{~T}_{2 \mathrm{~g}}$ transition of $\mathrm{Cr}^{3+}$ Oh and the ${ }^{5} \mathrm{E}_{\mathrm{g}} \rightarrow{ }^{5} \mathrm{~T}_{2 \mathrm{~g}}$ transition of $\mathrm{Cr}^{2+} \mathrm{Oh}^{\left[{ }^{[39,40]}\right.}$ EPR spectra of $\mathrm{Cr}$ species on oxide supports are reported to show three distinct signals, that is, $\beta$, $\gamma$ and $\delta .{ }^{[41,42]}$ EPR data (Figure $2 \mathrm{e}$ and $\mathrm{f}$ ) of the fresh catalyst shows only a $\gamma$-signal attributed to axially symmetric $\left[\mathrm{CrO}_{4}\right]^{3-}$ species (with $g_{x x}=g_{y y}=1.970$ and $g_{z z}=1.890$ ). Besides the reduction of $\mathrm{Cr}^{6+/ 5+}$, as testified by the appearance of a $\delta$ signal from dispersed $\mathrm{Cr}^{3+}$ ions $\left(g_{\text {eff }} \approx 3.7-6\right),{ }^{[41,42]}$ reaction with TEAl is causing the appearance of new, axially symmetric $\left(g_{x x}=g_{y y}=1.980\right.$ and $\left.g_{z z}=1.915\right)$ and rhombic $\mathrm{Cr}^{5+}$ species $\left(g_{x x}=1.980, g_{y y}=1.969, g_{z z}=1.922\right) \cdot{ }^{[41,42]}$ Furthermore, TEAl is not reducing $\mathrm{Ti}^{4+}$ species as confirmed by the absence of the EPR signal belonging to the isolated $\mathrm{Ti}^{3+}$ ions. ${ }^{[4-45]}$ After removal of heptane, ethylene and $\mathrm{H}_{2}$ were fed into the DRIFTS cell followed by the immediate start of the polymerisation of ethylene. Characteristic polyethylene $\mathrm{C}-\mathrm{H}$ stretching and deformation vibrations show a rapid rise in the $2800-3000 \mathrm{~cm}^{-1}$ region and at $1460 \mathrm{~cm}^{-1}$, respectively. ${ }^{[24-26]}$ The intermolecular interaction of the growing polyethylene chain with the silanol groups caused a decrease of the bands at $3745 \mathrm{~cm}^{-1}$ and $3720 \mathrm{~cm}^{-1}$ and their broadening and red shift to respectively $3695 \mathrm{~cm}^{-1}$ and $3650 \mathrm{~cm}^{-1}$. After the reaction, the UV-Vis-NIR DRS spectrum shows a further increase of the $\mathrm{d}-\mathrm{d}$ bands of $\mathrm{Cr}$ in lower oxidation states at the expense of $\mathrm{O} \rightarrow \mathrm{Cr}^{6+} \mathrm{CT}$ bands. The EPR $\delta$-signal assigned to dispersed $\mathrm{Cr}^{3+}$ species is even more pronounced, while the $\gamma$-signal shows a further distortion of the axially symmetric $\mathrm{Cr}^{5+}$ species, present after modification with TEAl, into new rhombic $\mathrm{Cr}^{5+}$ species $\left(g_{x x}=1.984, g_{y y}=1.976, g_{z z}=1.950\right)$.

It is well-known that at the start of the ethylene polymerisation the reactants diffuse into the pores and the crevices of the polymerisation catalyst. During the propagation step, the growing polymer causes fragmentation of the catalyst particle. This fragmentation was evidenced by the SEM images of the fresh catalyst particles and the particles after polymerisation in the DRIFTS cell (Figure $2 b$ and c) ${ }^{[46-48]}$ Due to the relatively mild ethylene partial pressure of 0.45 bar, the fragmentation of the catalyst particles was still at an early stage. However, the selection of these experimental conditions offered us the unique opportunity to study the ethylene polymerisation process at the initial steps of the fragmentation of the catalyst material induced during the formation of polyethylene.

As DRIFTS, EPR and UV-Vis-NIR DRS are bulk techniques, which give only an averaged set of information over a large amount of material, it is important to call in another more local characterisation method. In the second series of experiments, we have performed STXM as this method is a less invasive technique than energy dispersive $\mathrm{X}$ ray (EDX) analysis commonly attached to a SEM instrument (Figure S4 and S5) with respect to the sensitive polyethylene material. STXM offers nanoscale spatial information on the electronic and chemical structure of the catalyst and catalyst/ polymer materials. Figure 3 a shows the X-ray absorption 


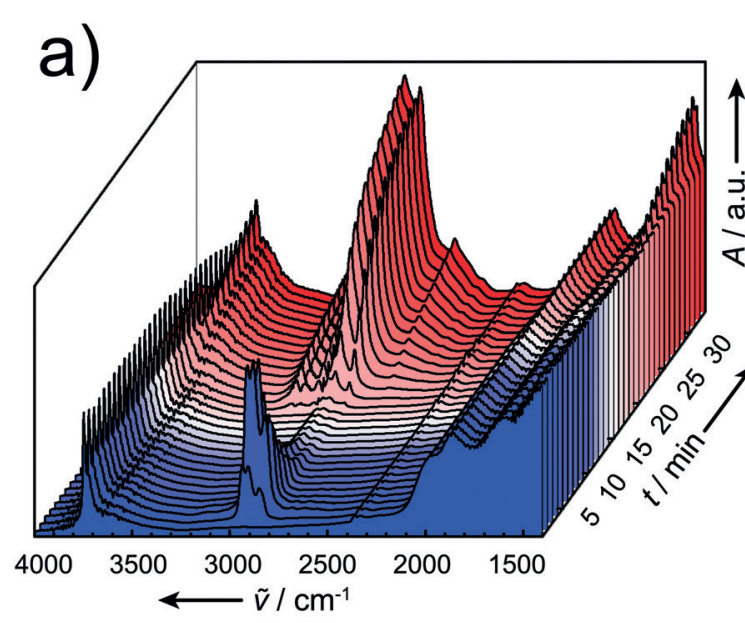

b)
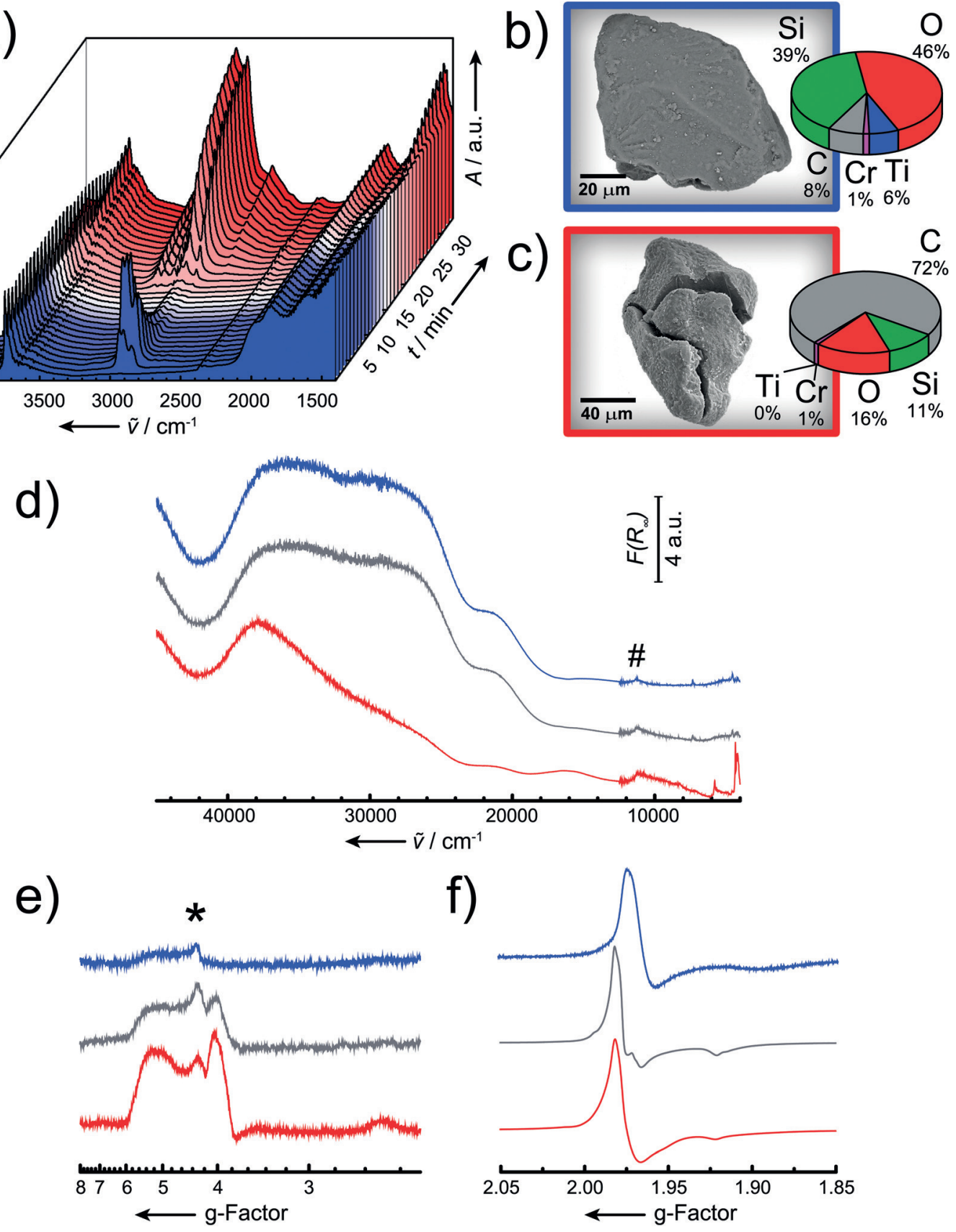

Figure 2. a) Time evolution of the DRIFT spectra of the $\mathrm{Cr} / \mathrm{Ti} / \mathrm{SiO}_{2}$ Phillips catalyst under study in the ethylene polymerisation reaction measured at $373 \mathrm{~K}$ and $1 \mathrm{bar}$. The catalyst was pre-contacted with TEAl during the first $5 \mathrm{~min}$, while the actual feed of the ethylene gas reactant mixture was started after $15 \mathrm{~min}$. The first spectrum shows (blue) the activated catalyst, middle (grey) the modification with TEAl, while the last spectrum corresponds with the catalyst containing polyethylene (red). The samples at these stages were further examined by SEM-EDX, STXM, EPR and UV-Vis-NIR DRS. b) SEM image of the fresh $\mathrm{Cr} / \mathrm{Ti} / \mathrm{SiO}_{2}$ Phillips catalyst before the addition of TEAl and polymerisation of ethylene. c) SEM image of the fragmented polyethylene/catalyst mixture after the in situ polymerisation of ethylene in the DRIFTS cell. EDX elemental analysis is presented in the pie charts (as wt \% values). d) UV-Vis-NIR DRS spectra show reduction of mono- and polychromate species in the fresh catalyst by TEAl and ethylene. Instrumental artefact is marked with \#. e) X-band EPR spectra showing the $\delta$-signal attributed to dispersed $\mathrm{Cr}^{3+}$ species. $^{2}$ impurity is marked with *. f) X-band EPR spectra showing the $\gamma$-signal from several $\mathrm{Cr}^{5+}$ species.

spectroscopy (XAS) spectra of all of the elements of the fresh Phillips $\mathrm{Cr} / \mathrm{Ti} / \mathrm{SiO}_{2}$ catalyst, collected using soft X-rays in the range of $450-1860 \mathrm{eV}$. The Si K-edge XAS spectrum in the spectral range from $1835-1860 \mathrm{eV}$ is indicative for $T_{d}$ coordinated $\mathrm{Si}^{4+}$ present within the $\mathrm{SiO}_{2}$ support. Regarding the $\mathrm{O}$ $\mathrm{K}$-edge in the spectral region of $525-580 \mathrm{eV}$, it was possible to distinguish between the $\mathrm{O}$ K-edge XAS spectrum of $\mathrm{SiO}_{2}$ and that of the epoxy resin, which was used for embedding the catalyst particle. Indeed, the $\mathrm{O} \mathrm{K}$-edge of $\mathrm{SiO}_{2}$ shows a $1 \mathrm{eV}$ blue shift to $538 \mathrm{eV}$ and a higher post-edge feature at $560 \mathrm{eV}$. Interestingly, the $\mathrm{Ti}_{2,3}$-edge XAS spectrum in the range of 452-477 eV shows separated $L_{3}$ and $L_{2}$ regions due to the 


\section{Angewandte}
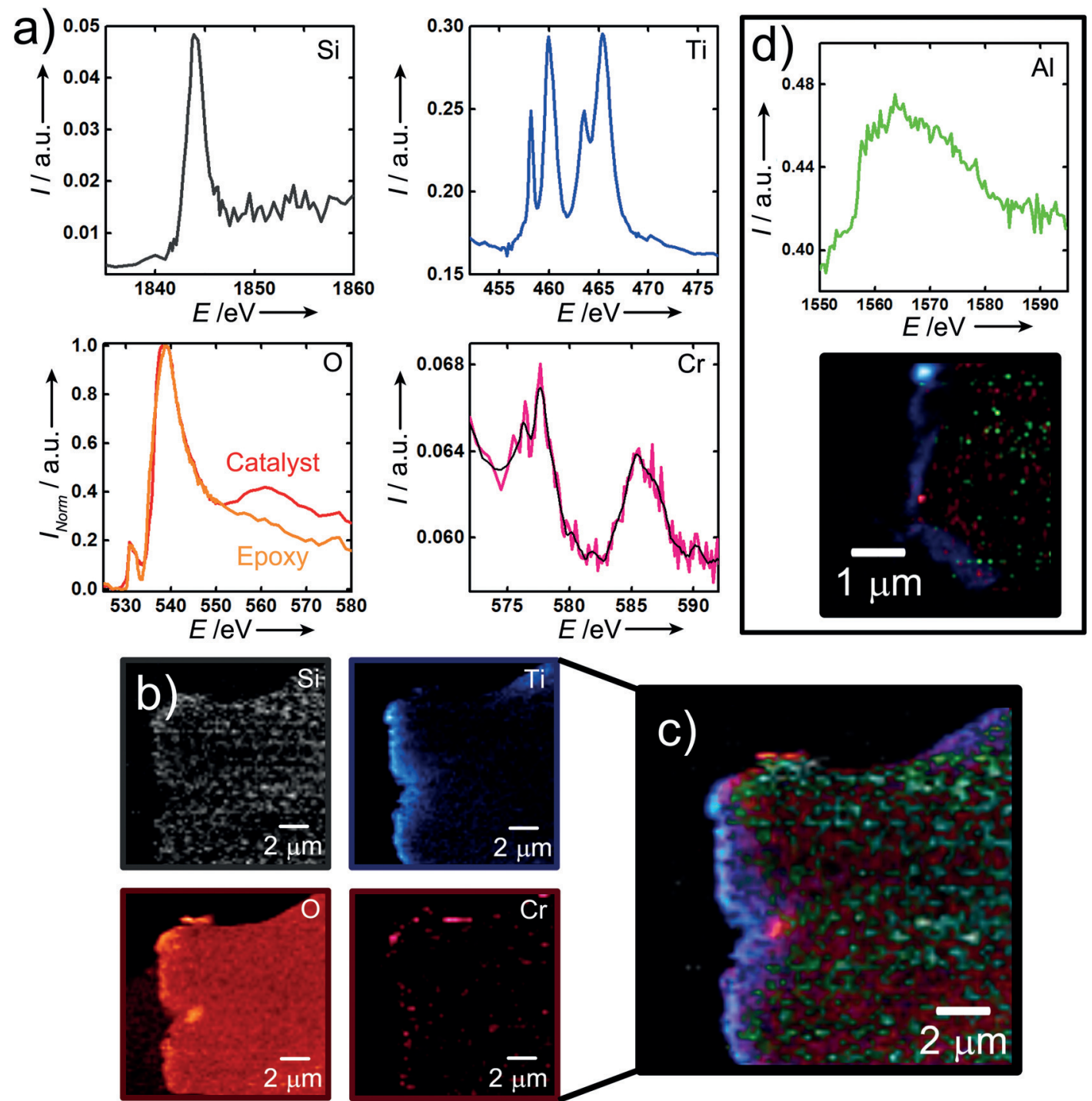

Figure 3. a) X-ray absorption spectroscopy (XAS) data of the chemical elements present in the fresh Phillips $\mathrm{Cr} / \mathrm{Ti} / \mathrm{SiO}_{2}$ catalyst under study: Si K-edge (grey), $\mathrm{Ti}_{2,3}$-edge (blue), O K-edge from the $\mathrm{SiO}_{2}$ support (red), O K-edge from the epoxy resin (orange) and $\mathrm{Cr}_{2,3}$-edge (purple) with a smoothed spectrum (black). The spectra were integrated over the examined region of the entire catalyst particle for achieving the best signal-tonoise ratio. b) Scanning transmission X-ray microscopy (STXM) elemental maps of the fresh Phillips $\mathrm{Cr} / \mathrm{Ti} / \mathrm{SiO}_{2}$ catalyst particle with c) an overlay of the STXM elemental maps. d) Al K-edge and elemental map of Ti (blue), $\mathrm{Cr}$ (purple) and Al (green) of the catalyst after the wet impregnation with TEAl for a nominal Al:Cr ratio of 1.

spin-orbit coupling of $\mathrm{Ti} 2 \mathrm{p}$ core electrons. Compared to reference spectra, ${ }^{[27,49]}$ it can be concluded that $\mathrm{Ti}^{4+}$ is in an $O_{h}$ coordination. $\mathrm{Ti}^{4+}$ does not belong to $\mathrm{TiO}_{2}$ crystallites, but is a part of a mixed amorphous oxide support of titania-silica showing no ordering or crystalline phases, which is confirmed by XRD (Figure S8).

The most challenging aspect of the performed STXM study is the low $\mathrm{Cr}$ content of the $\mathrm{Cr} / \mathrm{Ti} / \mathrm{SiO}_{2}$ Phillips catalyst. To the best of our knowledge, we present in Figure 3 a the first Cr $\mathrm{L}_{2,3}$-edge XAS spectrum of Phillips-type catalyst using STXM. The spin-orbit splitting of Cr causes distinct $\mathrm{L}_{2}$ and $\mathrm{L}_{3}$ regions in the spectral range of $572-592 \mathrm{eV}$. In comparison with the literature reference spectra, ${ }^{[50]}$ it can be concluded that $\mathrm{Cr}$ is most probably in a distorted $O_{h}$ state in the form of a dispersed $\mathrm{Cr}_{2} \mathrm{O}_{3}$-like phase. The oxidation number of the activated catalyst, calcined in dry $\mathrm{O}_{2}$, is expected to be +6 . Therefore, the lower oxidation state of $3+$ can be explained by the exposure of the activated catalyst to air, water and epoxy resin during the required preparation procedure for the STXM measurements, where $\mathrm{Cr}^{6+}$ has been partially converted into $\mathrm{Cr}^{3+}$.

Besides a detailed analysis of the measured XAS data, the STXM technique gives the opportunity of elemental mapping of a sample at the nanoscale. By subtracting a pre-edge image from the absorption edge spectral image it is possible to acquire an elemental map of each element under investigation. Using this procedure it was possible to obtain Figure $3 \mathrm{~b}$, which shows the elemental distribution of a Phillips $\mathrm{Cr} / \mathrm{Ti} /$ $\mathrm{SiO}_{2}$ catalyst particle, including a chemical element overlay map (Figure $3 \mathrm{c}$ ). 
The STXM $\mathrm{Si}$ and $\mathrm{O}$ maps show the mesoporous structure, which can also be inferred from $\mathrm{N}_{2}$ physisorption data (Figure S1) of the catalyst material. The STXM Ti map shows that $\mathrm{Ti}$ species are mostly located at the surface of the $\mathrm{Cr} / \mathrm{Ti} / \mathrm{SiO}_{2}$ catalyst particle forming a core-shell structure, which is in line with the applied preparation route and impregnation of the titanate ester. On the other hand, $\mathrm{Cr}$ species were found to be present more evenly throughout the whole catalyst particle. This non-uniform distribution of Ti and $\mathrm{Cr}$ is considered to be essential in the formation of at least two different types of active sites on a single particle, one mainly positioned in the Ti-abundant and the other one dominantly present in Ti-scarce catalyst particle regions, which are able to produce different types of polyethylene. Moreover, the elemental map of the catalyst sample pretreated with TEAl for the Al:Cr ratio of 1 (Figure $3 \mathrm{~d}$ ), shows that $\mathrm{Al}$ is well-dispersed into the catalyst core, which indicates that ethylene oligomerisation sites are neighbouring the (Tiscarce) ethylene polymerisation sites.

In order to evaluate this working hypothesis, we have conducted a detailed STXM study on the Phillips $\mathrm{Cr} / \mathrm{Ti} / \mathrm{SiO}_{2}$ catalyst after treating with the TEAl co-catalyst and ethylene feeding at $373 \mathrm{~K}$ and 1 bar in the in situ DRIFTS cell. The overall XAS image of the polyethylene/catalyst particle, given in Figure S9, shows a clear start of the catalyst fragmentation process. As with the fresh Phillips $\mathrm{Cr} / \mathrm{Ti} / \mathrm{SiO}_{2}$ catalyst, the

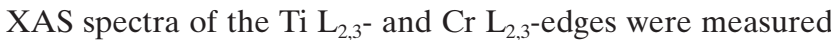
and are shown in Figure S10. After ethylene polymerisation, the $\mathrm{Ti}^{4+}$ remains $O_{h}$ coordinated, while Cr species were still detectable after reaction. The XAS spectrum of the $\mathrm{Cr} \mathrm{L}_{2,3}$ edge shows that $\mathrm{Cr}$ is distorted $O_{h}$ coordinated in the form of dispersed $\mathrm{Cr}_{2} \mathrm{O}_{3}$.

One of the most interesting aspects of this study has been the investigation of the absorption edge of the carbon species of the catalyst/polymer sample, probed in the energy range of 281-297 eV. Due to the distinctively different C K-edge XAS spectra it is possible to distinguish the carbon species of the produced polyethylene and the epoxy resin used for sample preparation. Figure 4 a shows the elemental maps of the $\mathrm{Ti}, \mathrm{Cr}$ and $\mathrm{C}$ together with a map overlay (Figure $4 \mathrm{~b}$ ). It was found that $\mathrm{Ti}$ remains located close to the surface of the catalyst particle except in the cracks of the fragmenting catalyst particle. In contrast, the $\mathrm{Cr}$ species are dispersed throughout the entire catalyst particle in the form of clusters, while the produced polyethylene is detected both on the outer surface of the catalyst particle and in the pores within the catalyst particle core with the highest optical density in the cracks of the fragmenting catalyst particle.

In order to investigate in detail the influence of the active polymerisation sites in the different regions within the catalyst particle, a more detailed analysis of the $\mathrm{C} \mathrm{K}$-edge in different parts of the particle has been performed. Two main different types of polyethylene were detected, as shown in Figure $4 \mathrm{c}$. Besides the characteristic $\mathrm{C} 1 \mathrm{~s} \rightarrow \sigma^{*}{ }_{\mathrm{C}-\mathrm{H}} / \mathrm{Ryd}$ transitions at 287.5 and $288 \mathrm{eV}$ of the $\mathrm{CH}_{2}$ groups of polyethylene species, inside the pores and the fragmentation cracks of the catalyst, the produced polyethylene shows an absorption spectrum very similar to the spectrum of the reference polypropylene sample with a more distinct $\mathrm{C} 1 \mathrm{~s} \rightarrow \sigma^{*}{ }_{\mathrm{C}-\mathrm{C}}$
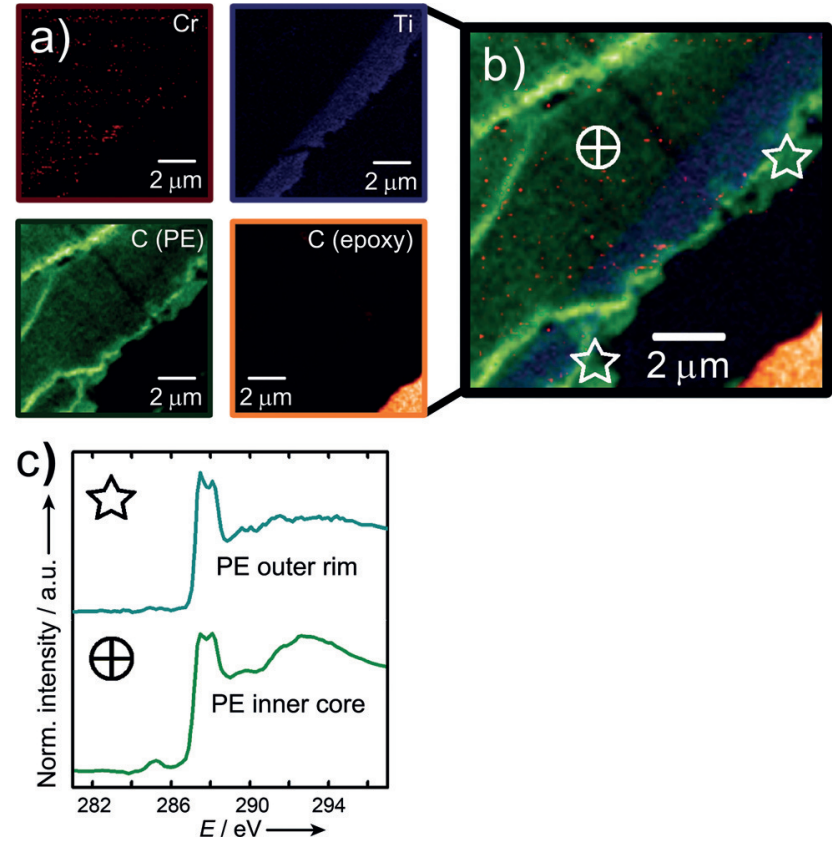

Figure 4. a) Scanning transmission X-ray microscopy (STXM) elemental maps of the Phillips $\mathrm{Cr} / \mathrm{Ti} / \mathrm{SiO}_{2}$ catalyst particle after ethylene polymerisation at $373 \mathrm{~K}$ and 1 bar. Carbon from the epoxy resin (orange), carbon from the polyethylene (green), $\mathrm{Ti}$ (blue) and $\mathrm{Cr}$ (purple). b) An overlay of the STXM elemental maps. c) XAS data of the $C$ K-edge from the PE layer on the outer rim of the catalyst particle (top) and of the PE within the cracks of the inner core of the catalyst particle (bottom)

transition band. ${ }^{[51-55]}$ Furthermore, detailed analysis of the $\mathrm{C} 1 \mathrm{~s} \rightarrow \sigma^{*}{ }_{\mathrm{C}-\mathrm{H}} / \mathrm{Ryd}$ bands shows a small widening towards lower energies caused by the $\mathrm{C} 1 \mathrm{~s} \rightarrow \sigma^{*}{ }_{\mathrm{C}-\mathrm{H}}$ transition at $285.1 \mathrm{eV}$ of the $\mathrm{CH}_{3}$ groups. These are the indications of the higher amount of branching of the polyethylene induced by the copolymerisation of the ethylene with the in situ generated ethylene oligomers, such as 1-hexene, inside the confined space of the catalyst pores. Furthermore, the low intensity band at $285.2 \mathrm{eV}$ assigned to $\mathrm{C} 1 \mathrm{~s} \rightarrow \pi^{*} \mathrm{C}=\mathrm{C}$ indicates the presence of olefin oligomers still adsorbed or trapped in the catalyst. It can be concluded that the active sites in the outer rim of the catalyst particle, containing predominantly both $\mathrm{Ti}$ and $\mathrm{Cr}$, produce more linear type of polyethylene with a lesser amount of branching than the core of the catalyst particle, which contain almost exclusively Cr. In this respect, it is important to mention that in the studies of the co-polymerisation of ethylene with light alpha olefins, such as 1-hexene, ${ }^{[1]}$ it is known that the presence of $\mathrm{Ti}$ on the Phillips catalyst tends to inhibit the incorporation of the co-monomer. Moreover, Ti could also inhibit co-monomer in situ generation and lead to a more pronounced reverse co-monomer incorporation, as co-monomer will mainly be generated in Ti-scarce areas where longer chains are produced.

This observation is in line with our data as the two distinct regions of the $\mathrm{Cr} / \mathrm{Ti} / \mathrm{SiO}_{2}$ catalyst particle clearly had different catalytic behaviour as the Ti-scarce active sites inside the core tend to induce the branching of the polyethylene chain, while the Ti-rich active sites inside the shell of the catalyst particle 
give a more linear type of polyethylene. This gives clear experimental proof of the position of the active sites responsible for the in situ oligomerisation of ethylene and the subsequent incorporation of the in situ produced light olefins, such as 1-hexene, into the growing polyethylene chain (Figure 5). We anticipate that the two different types of polyethylene produced by this bifunctional ethylene oligomerisation-polymerisation catalyst offer a clear perspective into advancing the production of an industrially important polyethylene with a simple Phillips-type catalyst from a single reactor system.

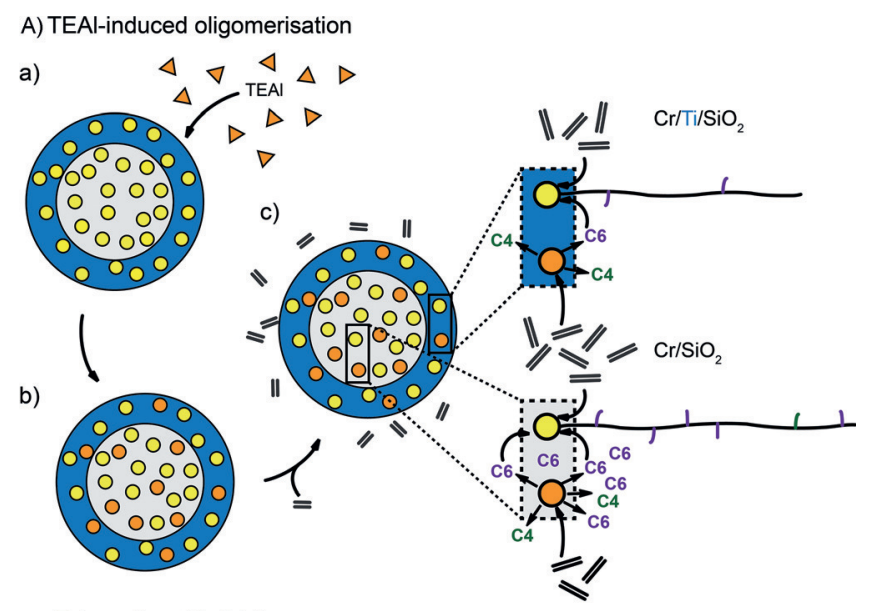

B) Externally added 1-hexene

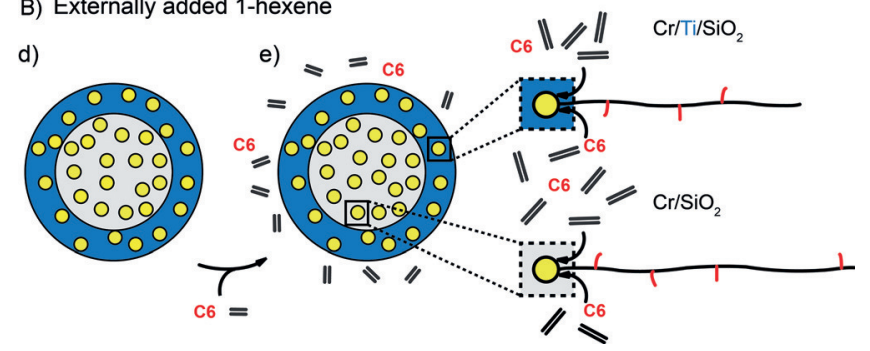

Figure 5. A) Schematic representation of polymerisation and oligomerisation active sites of a TEAl-modified shell-titanated $\mathrm{Cr} / \mathrm{Ti} / \mathrm{SiO}_{2}$ Phillips-type catalyst. a) TEAl (orange $\triangle$ ) is transforming some of the $\mathrm{Cr}$ polymerisation sites (yellow $\odot$ ) into b) ethylene oligomerisation sites (orange 0 ). c) Oligomerisation sites within the Ti-rich particle shell are producing less oligomers, that is, 1-hexene (C6) and 1-butene (C4). Therefore, nearby PE polymerisation sites that are making shorter chains in comparison to polymerisation active sites within the Tiscarce particle core, ${ }^{[1]}$ incorporate low amount of co-monomer. Oligomerisation sites within the Ti-scarce particle core are very efficient for the oligomerisation of ethylene, producing 1-hexene predominantly. Hence, PE polymerisation sites close-by, which are producing longer chains in comparison to polymerisation active sites close to $\mathrm{Ti}^{[}{ }^{[1]}$ incorporate a higher amount of co-monomer. This catalyst generates polyethylene with more co-monomer in the long chains, that is, reverse co-monomer incorporation. B) If 1-hexene is externally added into the reactor using a pristine $\mathrm{Cr} / \mathrm{Ti} / \mathrm{SiO}_{2}$ catalyst (d), co-monomer concentration is similar for all active sites, which lead to a typical Cr-based polyethylene with more commoner in short chains (e).

\section{Acknowledgements}

This research was funded by Total Research and Technology Feluy and Total SA. We acknowledge M. Versluijs-Helder and H. Meeldijk, both from Utrecht University (UU), for performing SEM-EDX and ultramicrotomy, respectively. The authors thank CLS for providing beamtime and the 10ID1 beamline scientists and the UU beamtime team, including M. al Samarai, K. Cats, S. Kalirai and R. Oord, for help in acquiring the STXM data. M. Delgado Jaime (UU) is acknowledged for the use of the Blueprint XAS program, while G. van Hauwermeiren and J. Decrom (Total Research and Technology, Feluy) are acknowledged for catalyst preparations.

Keywords: heterogeneous catalysis - in situ oligomerisation . Phillips catalyst - polyethylene .

scanning transmission x-ray microscopy

How to cite: Angew. Chem. Int. Ed. 2015, 54, 13073-13079 Angew. Chem. 2015, 127, 13265-13271

[1] M. P. McDaniel, Adv. Catal. 2010, 53, 123-606.

[2] E. Groppo, C. Lamberti, S. Bordiga, G. Spoto, A. Zecchina, Chem. Rev. 2005, 105, 115-184.

[3] B. M. Weckhuysen, R. A. Schoonheydt, Catal. Today 1999, 51, $215-221$.

[4] A. Zecchina, E. Groppo, Proc. R. Soc. London Ser. A 2012, 468, $2087-2098$

[5] R. Cheng, Z. Liu, L. Zhong, X. He, P. Qiu, M. Terano, M. S. Eisen, S. L. Scott, B. Liu, Adv. Polym. Sci. 2013, 257, 135-202.

[6] D. S. McGuinness, N. W. Davies, J. Horne, I. Ivanov, Organometallics 2010, 29, 6111-6116.

[7] J. P. Hogan, R. L. Banks, US2825721, 1958.

[8] J. P. Hogan, R. L. Banks, US2951816, 1960.

[9] G. Wilke, Angew. Chem. Int. Ed. 2003, 42, 5000-5008; Angew. Chem. 2003, 115, 5150-5159.

[10] L. L. Böhm, Angew. Chem. Int. Ed. 2003, 42, 5010-5030; Angew. Chem. 2003, 115, 5162-5183.

[11] A co-polymer with reverse co-monomer incorporation shows an increasing $\alpha$-olefin content with increasing co-polymer molecular weight, meaning a higher incorporation into longer than into shorter polymer chains. For more details we refer to the following textbook: J. B. P. Soares, T. F. L. McKenna in Polyolefin Reaction Engineering, Wiley-VCH, Weinheim, 2012, pp. 17 27.

[12] L. L. Böhm, H. F. Enderle, M. Fleifßner, Adv. Mater. 1992, 4, 234-238.

[13] R. Cheng, C. Xu, Z. Liu, Q. Dong, X. He, Y. Fang, M. Terano, Y. Hu, T. J. Pullukat, B. Liu, J. Catal. 2010, 273, 103-115.

[14] T. J. Pullukat, R. E. Hoff, M. Shida, J. Polym. Sci. Polym. Chem. Ed. 1980, 18, 2857-2866.

[15] M. P. McDaniel, M. B. Welch, M. J. Dreiling, J. Catal. 1983, 82, $118-126$.

[16] S. J. Conway, J. W. Falconer, C. H. Rochester, J. Chem. Soc. Faraday Trans. 1 1989, 85, 71-78.

[17] S. J. Conway, J. W. Falconer, C. H. Rochester, G. W. Downs, J. Chem. Soc. Faraday Trans. 1 1989, 85, 1841-1851.

[18] G. Debras, J.-P. Dath, EP0882743 B1, 1998.

[19] P. J. Deslauriers, M. P. McDaniel, J. Polym. Sci. Part A 2007, 45, $3135-3149$

[20] F. M. F. de Groot, E. de Smit, M. M. van Schooneveld, L. R. Aramburo, B. M. Weckhuysen, ChemPhysChem 2010, 11, 951962. 
[21] A. M. Beale, S. D. M. Jacques, B. M. Weckhuysen, Chem. Soc. Rev. 2010, 39, 4656-4672.

[22] a) B. M. Weckhuysen, Angew. Chem. Int. Ed. 2009, 48, 4910 4943; Angew. Chem. 2009, 121, 5008-5043; b) I. L. C. Buurmans, B. M. Weckhuysen, Nat. Chem. 2012, 4, 873-886.

[23] C. Barzan, D. Gianolio, E. Groppo, C. Lamberti, V. Monteil, E. A. Quadrelli, S. Bordiga, Chem. Eur. J. 2013, 19, $17277-$ 17282 .

[24] G. Socrates, Infrared and Raman Characteristic Group Frequencies: Tables and Charts, Wiley, Chichester, 2004, pp. 259-282.

[25] E. Groppo, C. Lamberti, S. Bordiga, G. Spoto, A. Zecchina, J. Catal. 2006, 240, 172-181.

[26] C. Lamberti, A. Zecchina, E. Groppo, S. Bordiga, Chem. Soc. Rev. 2010, 39, 4951-5001.

[27] P. Guttmann, C. Bittencourt, S. Rehbein, P. Umek, X. Ke, G. Van Tendeloo, C. P. Ewels, G. Schneider, Nat. Photonics 2011, 6, $25-29$.

[28] C. N. Nenu, E. Groppo, C. Lamberti, A. M. Beale, T. Visser, A. Zecchina, B. M. Weckhuysen, Angew. Chem. Int. Ed. 2007, 46 1465-1468; Angew. Chem. 2007, 119, 1487-1490.

[29] B. Liu, P. Šindelář, Y. Fang, K. Hasebe, M. Terano, J. Mol. Catal. A 2005, 238, 142-150

[30] W. Xia, B. Liu, Y. Fang, K. Hasebe, M. Terano, J. Mol. Catal. A 2006, 256, 301-308.

[31] W. Xia, B. Liu, Y. Fang, T. Fujitani, T. Taniike, M. Terano, Appl. Catal. A 2010, 389, 186-194.

[32] J. H. Lunsford, S.-L. Fu, D. L. Myers, J. Catal. 1988, 111, 231 234.

[33] B. Rebenstorf, J. Mol. Catal. 1989, 56, 170-182.

[34] D. L. Myers, J. H. Lunsford, J. Catal. 1986, 99, 140-148.

[35] D. L. Myers, J. H. Lunsford, J. Catal. 1985, 92, 260-271.

[36] a) M. P. Conley, M. F. Delley, G. Siddiqi, G. Lapadula, S. Norsic, V. Monteil, O. V. Safonova, C. Copéret, Angew. Chem. Int. Ed. 2014, 53, 1872-1876; Angew. Chem. 2014, 126, 1903-1907; b) M. P. Conley, M. F. Delley, G. Siddiqi, G. Lapadula, S. Norsic V. Monteil, O. V. Safonova, C. Copéret, Angew. Chem. Int. Ed. 2015, 54, 6670-6670; Angew. Chem. 2015, 127, 6771-6771.

[37] M. F. Delley, M. P. Conley, C. Copéret, Catal. Lett. 2014, 144 $805-808$.

[38] M. F. Delley, F. Núñez-Zarur, M. P. Conley, A. Comas-Vives, G. Siddiqi, S. Norsic, V. Monteil, O. V. Safonova, C. Copéret, Proc. Natl. Acad. Sci. USA 2014, 111, 11624-11629.
[39] B. M. Weckhuysen, L. M. De Ridder, R. A. Schoonheydt, J. Phys. Chem. 1993, 97, 4756-4763.

[40] B. M. Weckhuysen, A. A. Verberckmoes, A. L. Buttiens, R. A. Schoonheydt, J. Phys. Chem. 1994, 98, 579-584.

[41] B. M. Weckhuysen, L. M. De Ridder, P. J. Grobet, R. A. Schoonheydt, J. Phys. Chem. 1995, 99, 320-326.

[42] B. M. Weckhuysen, R. A. Schoonheydt, F. E. Mabbs, D. Collison, J. Chem. Soc. Faraday Trans. 1996, 92, 2431-2436.

[43] M. Anpo, M. Che, B. Fubini, E. Garrone, Top. Catal. 1999, 8, $189-198$.

[44] R. Bal, K. Chaudhari, D. Srinivas, S. Sivasanker, P. Ratnasamy, J. Mol. Catal. A 2000, 162, 199-207.

[45] K. Chaudhari, D. Srinivas, P. Ratnasamy, J. Catal. 2001, 203, 25 32.

[46] W. C. Conner, S. W. Webb, P. Spanne, K. W. Jones, Macromolecules 1990, 23, 4742-4747.

[47] K. W. Jones, P. Spanne, S. W. Webb, W. C. Conner, R. A. Beyerlein, W. J. Reagan, F. M. Dautzenberg, Nucl. Instrum. Methods Phys. Res. Sect. B 1991, 56/57, 427-432.

[48] X. Zheng, M. Smit, J. C. Chadwick, J. Loos, Macromolecules 2005, 38, 4673-4678.

[49] F. M. F. de Groot, J. C. Fuggle, B. T. Thole, G. A. Sawatzky, Phys. Rev. B 1990, 41, 928-937.

[50] C. N. Nenu, J. N. J. van Lingen, F. M. F. de Groot, D. C. Koningsberger, B. M. Weckhuysen, Chem. Eur. J. 2006, 12, 4756-4763.

[51] H. W. Ade, A. P. Smith, G. R. Zhuang, J. Kirz, E. G. Rightor, A. P. Hitchcock, J. Electron Spectrosc. Relat. Phenom. 1996, 84, $53-72$.

[52] O. Dhez, H. W. Ade, S. G. Urquhart, J. Electron Spectrosc. Relat. Phenom. 2003, 128, 85-96.

[53] S. G. Urquhart, A. P. Hitchcock, A. P. Smith, H. W. Ade, E. G. Rightor, J. Phys. Chem. B 1997, 101, 2267-2276.

[54] S. G. Urquhart, A. P. Hitchcock, A. P. Smith, H. W. Ade, W. Lidy, E. G. Rightor, G. E. Mitchell, J. Electron Spectrosc. Relat. Phenom. 1999, 100, 119-135.

[55] G. Hähner, Chem. Soc. Rev. 2006, 35, 1244-1255.

Received: July 21, 2015

Revised: August 17, 2015

Published online: September 9, 2015 